\title{
ECONOMIC EFFICIENCY OF DETERMINING THE MARKET PRICE OF CONSTRUCTION RESOURCES WITHIN THE LIMITED BUDGET
}

\author{
Serhii Sichnyi ${ }^{1}$
}

\begin{abstract}
The article examines the analysis of current prices in the market of building materials, products, structures, machines, and mechanisms (construction resources), which is performed by construction participants. The aim of the article is to study the possibility of achieving the maximum economic effect of the analysis of current prices in the market of construction resources within a limited budget. A universal mathematical approach is proposed to calculate the economic effect of the analysis of current prices in the market of construction resources, which is based on a selective method of the research of the market value of construction resources. The calculations take into account the difference between the real resources presented on the market and the estimated construction resources (resource position of the estimate), between the market price and the estimated market price of the construction resource. While performing the analysis of current prices on the market of construction resources in the given conditions of the limited budget the option to reduce the general list of resources by a selection of the optimum list with an application of methods of discrete optimization is offered. The condition for the formation of an abbreviated list of resources is the maximum economic effect that can be obtained from the analysis of current prices for selected resources. Method of heuristic rules is proposed, which allow to significantly reducing the initial list of resources by a simple analysis of input data. The application of these rules allows to reduce the variability of input data for discrete optimization or not to carry it out at all, because the amount of resources selected with their help satisfies the condition of the budget constraint. Recommendations on the composition of the source data are given - this is the project documentation and/or the market price of construction resources as a basis for comparison and information on the range of market prices (scope of sample variation) for the resources included in the study. In the article there are given examples of the practical application of the technique in the conditions of the construction industry in Ukraine. In general, the proposed approach can be used at all stages of variant BIMdesign, when it is necessary to determine the most optimal composition of structures and resources that meet the requirements for the life cycle of the object. Including under the condition of gradual detailing of constructs (an increase of LOD of the project), during designing, up to resources at a stage "Working project". The main advantages of the proposed method are universality - it does not depend on the ultimate goal of the results of the customer and / or contractor and scalability - it can be applied to the structure, its individual design, or several resources.
\end{abstract}

Key words: cost of resources in construction, cost of construction, market research, determination of market value of construction resources, analysis of current prices in the market of construction materials, estimated price of resources.

\section{JEL Classification: C81, D81, L74}

\section{Introduction}

A typical financial and economic goal during construction is to make a profit for the builder and save money for the customer (investor). Both are achieved by reducing the cost of construction resources, which is impossible without a study of the construction resources market within a highly competitive market.

\footnotetext{
Corresponding author:

1 "Construction - Modern Technologies", Ukraine.

E-mail: Sichnyi.S@gmail.com

ORCID: https://orcid.org/0000-0002-8340-7521
}

The analysis of current prices on the market of construction materials, products, constructions, machines, and mechanisms (construction resources) envisaged by National Standards of Ukraine (Minrehion, DSTU B D.1.1-1:2013, 2013) aims to save public funds. For the contractor, such market research is necessary to obtain maximum profit when performing construction work. The ultimate 
goal is different, but the local goal of market analysis is the same - to determine the real market prices of construction resources for informed decision-making related to the activities of the enterprise.

At first glance, it seems that we are dealing with a "standard" marketing or statistical market research. Moreover, the modern methodological developments and technical capabilities allow to conduct a market research with high accuracy (low error), even for very complex systems. But there are several reasons that require a separate analysis of the market of construction resources:

- investigation of the market value of construction resources, in addition to the accuracy, are subject to strict restrictions on their duration;

- the list of construction resources for which it is necessary to carry out the analysis, is dynamic. Its size and structure depends on the construction site and the composition of the construction work on it. During construction, this list changes monthly;

- the names of resources in the project documentation are generalized with information about the purpose and main technical characteristics of the construction resource. They do not contain the names of specific brands and often do not take into account the terminology of manufacturers and/or suppliers. Therefore, the formation of the list of suppliers to determine the market price of the construction resource can be carried out only after determining the list of real market names that most accurately correspond to the generalized name of the resource in the project documentation;

- for projects implemented using BIM-technologies, the resource can be a construct that is gradually detailed into smaller constructs up to individual resources (from LOD 100 to LOD 500).

However, the cost of such work is limited. At a minimum, it may not exceed the savings of the construction customer or the contractor's profit from such an analysis of current prices. Therefore, the question of the maximum effectiveness arises in terms of research within a limited budget.

\section{Analysis of recent research and publications}

In post-Soviet countries, data collection and processing techniques for determining weighted average current prices are based on information about construction work that was already performed. It means that data is collected about past events - deliveries that have already taken place. With the resource method, which operates in Ukraine, the current prices must be determined before the start of work - before the supply of resources to the object. Domestic research states the need for work to determine current prices (Berkuta, 2000), however, there are no appropriate methods.
The need to use in the estimated current market (regional) prices for construction resources is noted in the works of specialists in various fields from the standpoint of pricing, setting, and regulating the price of construction products (Matveychuk, 2009; Reznichenko, 2006), from the standpoint of efficiency (profitability) of investment activities (Nikolayev, 2011), planning and cost reduction of the customer, from the standpoint of design and construction (Berkuta, 2000). The complexity of the problem is determined. In the works by Reznichenko (Reznichenko, 2006), approaches to the formation of the structure of data banks of current market prices and some methods of indirect determination of the price of resources are formulated.

Theoretical bases for determining the market price of construction resources were proposed in 2013 (Sichniy, 2013). They became the basis for the development of SOU-N D 1.1-34623477-001: 2015 "Procedure for the analysis of prices for material and technical resources used for construction work", which is implemented in practice and used by Analytic Center "Construction - Modern Technologies" LLC, Ivano-Frankivsk, in providing services to construction market participants.

Separate attempts to study the economic efficiency of work to determine market prices of construction resources (Sichniy, 2013; Sichnyi, 2017) are not enough.

The aim of the article is to investigate the possibilities of achieving the maximum economic effect of the analysis of current prices in the market of construction resources within a limited budget.

\section{Analysis of the current prices in the market of construction resources}

To solve these problems, we can use methods of marketing research, which are based on the system of marketing information (Kotler, 2020): "Analysis of current prices in the market of construction resources is a systematic determination of the list of resources needed to perform the work, collecting data on their cost, analysis of the collected data and a report on the result." The scheme of research (Kotler, 2020) will look like the image below.

Without delving into the types of data (primary, secondary) and methods of their collection, we are going to consider the problem of optimal allocation of funds for work to determine the market price of construction resources.

Let the project provide for the use of $\mathbf{H}$ estimated resources with a total estimated value of $\mathbf{B}$. Set as well the amount of funds $\mathbf{R}$, which can be spent on the analysis of current prices in the market of construction resources by structure. 


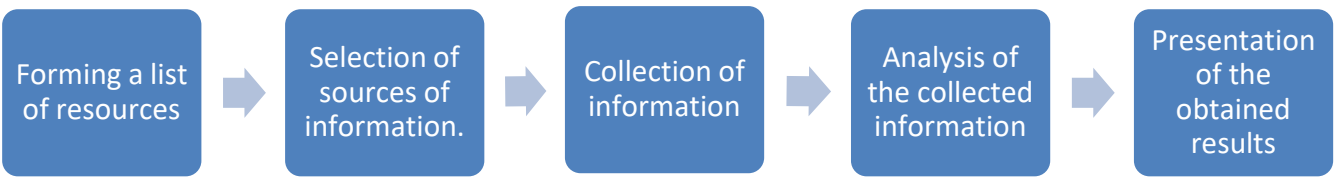

Figure 1. The scheme of analysis of current prices in the market of construction resources

The cost of determining the market price of the i resource depending on the sample size can be represented as

$$
S_{i}=a_{i}+b_{i} n_{i}
$$

where:

$a_{i}$ is the fixed costs (which do not depend on the sample size),

$b_{i} n_{i}$ is the variable costs proportional to the sample size.

$n_{i}$ is the sample size in the $\mathrm{i}$-th estimated resource.

Estimated resource (resource position according to (Minrehion, DSTU-N B D.1.1-6:2013, 2013)) is a general name of a group of materials, products or machines. Therefore, in fact:

$$
n_{i}=n_{1}+n_{2}+n_{3}+\ldots+n_{p}
$$

where:

$p$ is the number of products or machines with equal characteristics; however, produced by different brands or manufacturers which correspond to the design characteristics of the estimated resource (resource position).

Fixed costs include organizational costs, transportation costs, training, and so on.

Variable costs include payment for the working time of specialists who perform the work (working time, of course, in proportion to the sample size), travel expenses, etc.

The total estimated cost of all resources consists of the average market estimated values of all resources of the project:

$$
\begin{aligned}
& B=\sum_{1}^{H} \bar{B}_{i} \\
& \bar{B}_{i}=\bar{L}_{i} \times K_{i}
\end{aligned}
$$

where:

$\bar{B}_{i}$ is an average market estimated value of one estimated resource;

$K_{i}$ is the estimated amount of the resource.

$\bar{L}_{i}$ is the average market estimated price of the estimated resource;

Average market estimated price of the estimated resource:

$$
\bar{L}_{i}=\frac{\sum_{1}^{k} u_{i}}{k}
$$

where:

$u_{i}$ is the estimated price in the i market supply of the estimated resource;

$k$ is the total number of market offers of the estimated resource.
The estimated price of material resources according to (Minrehion, DSTU-N B D.1.1-2:2013, 2013) is determined by the on-site composition of the construction site and the established unit of measurement that takes into account the following elements of value:

- selling price (including the cost of containers, packaging and props and the cost of cargo work);

- cost of transportation;

- procurement and warehousing costs.

Since the full set of suppliers (sellers) for most construction resources in a particular region is always unknown - their complete list does not exist, it is obvious that for most construction resources it is impossible to cover and collect all the proposals. Therefore, to determine the average market estimated price, it is most appropriate to use the sampling method.

Each estimated resource will have its own sample size (Sichniy, 2013) and the average market estimated price of the resource will be defined as:

$$
\overline{L_{i}}=\bar{u}_{i} \pm \Delta_{i}
$$

where: $\bar{u}_{i}$ is the average price in the sample of the $\mathrm{i}$-th market supply of the resource;

$\varnothing_{i}$ is sampling error.

Guaranteed estimated price at which we will be able to purchase an estimated resource in the construction region:

$$
\bigsqcup_{i}^{\text {2ap }}=\bar{u}_{i}+\Delta_{i}
$$

Denote $3_{i}$ is the change in the price of the resource in comparison with the design estimated price of the $\mathbf{i}$ as estimated resource.

Then the economic effect (total savings of the customer or the contractor's profit) can be calculated by the formula:

$$
E E=\sum_{1}^{H N} K_{i} \times\left(\bar{u}_{i}+\Delta_{i}\right) \times 3_{i}
$$

Sampling error:

$$
\Delta_{i}=\frac{t \times \sigma_{i}}{\sqrt{n_{i}}}
$$

where:

$t$ is a tabular value, for a sample of more than $30 t=2.58$;

$\sigma_{i}$ is general variance of price proposals of the $i$ as estimated resource.

\section{Ways to achieve maximum economic effect}

Within a limited budget $\mathbf{R}$, it may be impossible to determine the market prices of all estimated $\mathbf{H}$ 
resources provided by the project. Then it is necessary to solve the problem of optimal distribution of funds for the work to analyse the market price of construction resources for the project: to determine the list of resources provided by the project and the sample size $n_{\mathrm{i}}$ for these resources so that the value:

$$
E E=\sum_{1}^{H N} K_{i} \times\left(\bar{y}_{i}+\frac{t \times \sigma_{i}}{\sqrt{n_{i}}}\right) \times 3_{i}
$$

was the maximum at a given limit:

$$
\sum_{1}^{H N}\left(a_{i}+b_{i} n_{i}\right) \leq R
$$

where:

$\mathrm{R}$ is the amount of money that can be spent on work to determine the market price of resources for the structure.

If you analyze all the resources included in the project, then the task is to allocate variable costs so as to minimize

$$
\sum_{1}^{H} \frac{q_{i}}{\sqrt{n_{i}}} ; \text { where: } q_{i}=t \tilde{A}_{1} 3_{i} K_{i}
$$

with restriction:

$$
\sum_{1}^{H} b_{i} n_{i} \leq R-\sum_{1}^{H} a_{i}=R(H)
$$

This problem is solved using the method of Lagrange multipliers.

Its optimal solution:

$$
n_{i}=\frac{\left(q_{i} / b_{i}\right)^{2 / 3}}{\sum_{1}^{H} q_{j}^{2 / 3} b_{j}^{1 / 3}} R(H)
$$

The value (7) will be equal to:

$$
\left(\sum_{1}^{H} q_{j}^{2 / 3} b_{j}^{1 / 3}\right)^{3 / 2} * R(H)^{-1 / 2}
$$

and the expected economic effect will be

$$
\mathrm{EE}=\sum_{1}^{H} \overline{x_{i}} \mathrm{~K}_{i} 3_{i}+\left(\sum_{1}^{H} q_{j}^{2 / 3} b_{j}^{1 / 3}\right)^{3 / 2} * R(H)^{-1 / 2}
$$

It is known that the list of resources includes price making part wherein the total cost makes a significant role and there are resources where the total cost is within the statistical error. Therefore, the task of efficient use of funds can be complicated by selecting the most optimal list of resources for the analysis of market prices from their general list. The task of selecting the optimal list of resources is to determine the set $\mathbf{H}$, for which (13) takes the maximum value. This task belongs to the type of discrete optimization tasks (Akimov, 2005). Heuristic rules can be applied to simplify the problem.

\section{For Example}

1. We assume that the analysis of the market price of estimated resources with the highest estimated value will bring the greatest economic effect and sort resources by decreasing estimated value. We accept the limit of pricing resources (80\%-95\%) of the total estimated cost. We obtain a significantly reduced list of resources (Sichnyi, 2017) for which the task of finding the extremum for (13) is simplified.

2. We assume that the largest variance of the sample will be in the resources with the largest range of market prices (scope of sample variation) and for them, the economic effect of the analysis will be greater. We sort resources by decreasing the estimated value and, in addition, taking into account the market price range.

The correctness (accuracy) of the calculation of the possible economic effect largely depends on the basis of comparison - the design estimated price of the $\mathrm{i}$ estimated resource and the sampling error. This is clearly seen in (6) which may look different:

$$
E E=\sum_{1}^{H} K_{i} \times\left(\bar{u}_{i}+\Delta_{i}-u_{i}^{\text {koum }}\right)
$$

where: $u_{i}^{\text {Koum }}$ is the design estimated price of the $\mathrm{i}$ as estimated resource.

\section{Practical implementation}

An example of practical application is the analysis of current prices in the market of construction resources for the project: "Overhaul of the superstructure of the berth №9", which was performed by Analytic Center "Construction - Modern Technologies" LLC, Ivano-Frankivsk, in 2016. The customer set the task to determine the lowest cost of construction resources in the project before the examination of the project documentation and in connection with the preparation for the procurement procedure.

The initial data for the work was a statement of resources for the project, specifications and drawings of reinforced concrete products of special construction.

Due to time constraints and budget, the customer was asked to analyze the current selling prices of suppliers for pricing materials, products and structures that are at least $90 \%$ of the total cost of section IV "Building materials, products and structures" resource information to project. The results of the analysis of current prices in the market of construction resources are shown in Table 1.

Here are a few more problems where the proposed mathematical apparatus can already be used:

- The investor wants to increase the market price of the object by using more expensive, more prestigious materials on its construction. The new, possible, market price of the object is known from the study of the price of competitors. But to assess how sales revenue will change, it is necessary to determine how the cost of purchasing new materials will change.

- The construction company decides to take part in the tender for the construction of facilities in another region. The company has experience, qualified personnel, 
Table 1

The results of the analysis of current prices in the market of construction resources for the project: “Overhaul of the upper structure of the moorage № 9”

\begin{tabular}{|l|c|c|}
\hline \multicolumn{1}{|c|}{ Indicator } & According to the project & According to the analysis \\
\hline The number of items in the resource statement & 222 & 222 \\
\hline Number of resource items for analyze & 130 & 80 \\
\hline Total selling price of resources for analysis, UAH & $8,354,360$ & 98 \\
\hline $\begin{array}{l}\text { The limit for pricing resources of the total cost of material } \\
\text { resources in the statement of resources, } \%\end{array}$ & 90 & $7,748,646$ \\
\hline $\begin{array}{l}\text { The total average selling price of resources for which the } \\
\text { analysis was actually conducted, UAH }\end{array}$ & $8,166,127$ \\
\hline $\begin{array}{l}\text { The total minimum cost of resources for which the analysis } \\
\text { was actually conducted, UAH }\end{array}$ & - & $7,114,956$ \\
\hline $\begin{array}{l}\text { Economic effect, calculated from the total cost of average } \\
\text { resource prices for which the analysis was performed, } \%\end{array}$ & 5.1 \\
\hline $\begin{array}{l}\text { Total average selling price of resources in the statement } \\
\text { of resources ( } B=\sum_{1}^{H} \bar{B}_{i} \text { ), UAH }\end{array}$ & $8,354,360$ & $7,936,879$ \\
\hline $\begin{array}{l}\text { The total minimum cost of resources in the statement } \\
\text { of resources, } \mathrm{UAH}\end{array}$ & - & $7,303,189$ \\
\hline $\begin{array}{l}\text { Economic effect of the analysis, calculated from the total cost } \\
\text { of average prices on the statement of resources (EE), } \%\end{array}$ & & 5.0 \\
\hline
\end{tabular}

and had done similar projects. For the well balanced decision making, you need to know how direct costs will change, the main component of which is the cost of construction resources in a new, for the company, the construction region.

- The investor needs to assess their financial capabilities before starting the construction of the facility for which the project documentation was developed several years ago. To make a decision, it is not necessary to list all the estimate documentation; it is enough to assess how the estimated cost of construction resources has changed.

- The investor needs to "tie" a typical project to a construction site in another region. A list of all estimated resources is known from the previously implemented project. It is possible to determine the economic feasibility (financial feasibility) of construction by examining the market value of resources in the region of "binding".

\section{Conclusions}

The proposed approach can be used:

- in BIM-design when in the early stages there is no list of resources, but there is a list of constructs, which gradually, during the design, is detailed, up to the resources at the stage of "Working project";
- for variant design, when it is necessary to determine the most optimal composition of structures and resources for the longest or cheapest life cycle of the object.

The main advantages of this approach are that: - it is scalable: it can be applied to a structure, its separate construct, or several resources.

- it is universal: regardless of the purpose of application of results it can be used by all participants of the construction market - the investor (customer), the contractor, the designer, the engineer-consultant, the monitoring (controlling) organizations.

For the maximum efficiency of use of the offered mathematical apparatus the enterprises need qualitative initial data:

- Design documentation and/or market price of construction resources as a basis for comparison;

- Market price range (scope of sample variation) for resources;

Such data can be collected at our own facilities and obtained as a service from specialized organizations.

The state, as the largest customer of construction works, is interested in forming and supporting the market of such information services. Competition in this area will contribute to the transparency of calculations and ultimately to the establishment of a civilized construction market.

\section{References:}

Akimov, O. (2005). Diskretnaia matematika: logika, grupi, grafy, fraktaly. Moskva: Izdatel AKIMOVA.

Berkuta, A. H. (2000). Reformuvannia tsinoutvorennia - shliakh do tsyvilizovanoho rynku. Tsinoutvorennia u budivnytstvi. Zbirnyk ofitsiinykh dokumentiv ta roziasnen, vol. 3.

Kotler, P. (2020). Marketing: An Introduction, 5th Edition (Ukrainian). Kyiv: Dialektyka-Viliams. 
Matveychuk, V. (2009). Effektivnost evropeiskoi sistemy tcenoobrazovaniia pri realizatcii investitcionnykh proektov. Derzhava ta rehiony. Seriia: Ekonomika ta pidpryiemnytstvo, vol. 1.

Minrehion, U. (2013). DSTU B D.1.1-1:2013. «Pravyla vyznachennia vartosti budivnytstva». Kyiv.

Minrehion, U. (2013). DSTU-N B D.1.1-2:2013. «Nastanova schodo vyznachennia priamykh vytrat u vartosti budivnytstva $\gg$. Kyiv.

Minrehion, U. (2013). DSTU-N B D.1.1-6:2013. «Nastanova schodo rozroblennia resursnykh elementnykh koshtorysnykh norm na budivelni roboty». Kyiv.

Mizhuriadova Rada zi spivrobitnytstva v budivelnii diialnosti, M. R.-u. (2012). Kontseptsiia intehruvannia system tsinoutvorennia derzhav - uchasnyts SND i vprovadzhennia innovatsijnykh metodiv vyznachennia vartosti budivnytstva na vsikh stadiiakh investytsijno-budivelnoho protsesu. Astana.

Nikolayev, V. P. (2011). Informatsionnoye i normativnometodicheskoye obespecheniye analiza zhiznennogo tsikla kapitalnykh investitsiy. Formuvannya rinkovikh vidnosin v Ukraini, vol. 9, pp. 88-93.

Reznichenko, V., Lenintsev, Ya., \& Mizyun, V. (2006). Organizatsionno-ekonomicheskiye problemy i mekhanizmy snizheniya stoimosti stroitelnoy produktsii. Ekonomika Stroitelstva, vol. 1.

Sichnyi, S. (2013). Do problem obgruntuvannya vartosti materialiv u budivnytstvi. Budivelne vyrobnytstvo. Mizhvidomchyi naukovo-tekhnichnyi zbirnyk, vol. 55, pp.79-87.

Sichnyi, S. (2017). Zmenshennia vytrat pry provedenni analizu tsin na rynku budivelnykh materialiv. Budivelne vyrobnytstvo. Mizhvidomchyi naukovo-tekhnichnyi zbirnyk, vol. 63/2, pp. 85-91. 